\title{
Phosphate Fertilization and Liming Promote the Growth and Development of Annona crassiflora
}

\author{
Andréia Mendes da Costa ${ }^{1}$ (1) 0000-0003-0395-6190 \\ Nelson Venturin ${ }^{2}$ (1) 0000-0001-8397-8984 \\ Regis Pereira Venturin ${ }^{3}$ (1) 0000-0002-2309-4367 \\ Patrícia Oliveira da Silva ${ }^{1}$ (D) 0000-0003-2242-320X \\ Leandro Carlos $^{1}$ (10) 0000-0003-1736-6079
}

\begin{abstract}
Annona crassiflora is a medicinal species and source of food with little information about its nutritional requirements during the initial phase. Therefore, the objective of this study was to evaluate liming, phosphate fertilization and its interaction in $A$. crassiflora seedlings. The experiment was in a $4 \times 4$ factorial scheme with four replications in a randomized block design. The base saturations were: $8.3 \%, 25 \%, 50 \%$ and $75 \%$ and phosphorus: $0 \mathrm{mg} \mathrm{dm}^{-3}$, $100 \mathrm{mg} \mathrm{dm}^{-3}, 200 \mathrm{mg} \mathrm{dm}^{-3}$ and $400 \mathrm{mg} \mathrm{dm}^{-3}$. The variables evaluated were biometrics, biomass and nutritional analysis. The species responded to the factors in isolation, and the increase in base saturation levels and phosphorus doses promoted significant effects for biometric variables, biomass, calcium, magnesium, nitrogen, phosphorus and potassium content. The saturation level promoted the best results, being $75 \%$ base saturation, while the highest phosphorus dosage was $400 \mathrm{mg} \mathrm{dm}^{-3}$.
\end{abstract}

Keywords: marolo, forest nutrition, seedling formation, nutritional requirement.

\section{INTRODUCTION AND OBJECTIVES}

Among the native fruits of the Cerrado region, Annona crassiflora Mart. (popularly known as marolo or araticum) stands out as it presents great potential as a source of food, traditional/folk medicine and in the field of the cosmeceutical industry (Bailão et al., 2015; Botrel et al., 2016; Valadares et al., 2015). Thus, in recent times there has been increasing interest in producing seedlings of native species not only destined for food and medicine, but also for the conservation and recovery of degraded areas; yet, little is known about many of the native species of the Cerrado (Souza et al., 2018).

Some authors have verified responses to liming and phosphating for other species of the Annonaceae family (Freitas et al., 2013; Rozane \& Natale, 2014), but there is only one report specifically for $A$. crassiflora in which it responds well to liming, but it did not reach an ideal of base saturation for the species (Ferreira et al., 2009). Therefore, there is still a great need for information on the nutrition of this species.

The practice of liming has elevated the growth of several species due to the benefits that this practice offers, among them, elevated hydrogenation potential, neutralization of toxic aluminum $\left(\mathrm{Al}^{3+}\right)$, addition of calcium $\left(\mathrm{Ca}^{2+}\right)$ and magnesium $\left(\mathrm{Mg}^{2+}\right)$ to the soil which increases base saturation, creating more favorable conditions to root growth, consequently increasing water and nutrient uptake (Freitas et al., 2017). Calcium and magnesium additions are extremely important because they are components of fundamental structures in plants such as the cell wall and chlorophyll molecules, respectively (Santin et al., 2013).

Phosphate increases the phosphorus content available to plants, which is one of the most required nutrients by plants as it participates in the metabolic processes, especially in photosynthesis and respiration, being products of carbon

\footnotetext{
${ }^{1}$ Instituto Federal de Educação, Ciência e Tecnologia Goiano (IF Goiano), Rio Verde, GO, Brasil

${ }^{2}$ Universidade Federal de Lavras (UFL), Lavras, MG, Brasil

${ }^{3}$ Empresa de Pesquisa Agropecuária de Minas Gerais (Epamig), Lavras, MG, Brasil
} 
metabolism. In addition, it is part of several organic compounds involved in the phosphorylation of phospholipid in the cell membrane required for synthesizing NADPH and ATP forming $\mathrm{NADP}^{+} / \mathrm{ADP}$, i.e. chemical binding energy (Shabnam \& Iqbal, 2016). It is responsible for promoting the increase in the photoassimilate production for the plants, stimulating the growth and development of both the root system and the shoot (Li et al., 2016; Taiz \& Zeiger, 2017).

Accordingly, the necessity of studies with liming and phosphate fertilization in A. crassiflora seedlings is evident. Therefore, the objective of this study was to evaluate the influence of phosphate fertilization, liming and its interaction on growth and mineral nutrition of Annona crassiflora Mart. seedlings.

\section{MATERIALS AND METHODS}

The experiment was conducted in a greenhouse of the Agricultural Research Corporation of Minas Gerais, Brazil (Epamig) at the Technological Center in the South of Minas Gerais, Lavras. The soil used was classified as dystrophic Red Latosol (dRL) (Embrapa, 2013). The soil sample was composed of five different points in the layer from $0 \mathrm{~cm}$ to $20 \mathrm{~cm}$ depth, and later taken for chemical and physical characterization (Silva, 2009). The results of these analyses are shown in Table 1. The base saturation of the natural soil was $8.3 \%$, and the granulometric analysis indicated that the soil presented $58 \%$ clay, $29 \%$ silt and $13 \%$ sand.

The experiment was installed in a $4 \times 4$ factorial scheme with four replications, totalizing 64 experimental units, and the experimental design was a randomized complete block design. The base saturation levels were: $8.3 \%$ - natural, $25 \%$ (0.69 ton ha ${ }^{-1}$ limestone), $50 \%$ (1.74 tons ha ${ }^{-1}$ limestone), $75 \%$ (2.77 tons ha ${ }^{-1}$ limestone) and $0 \mathrm{mg} \mathrm{dm}^{-3}, 100 \mathrm{mg} \mathrm{dm}^{-3}, 200 \mathrm{mg} \mathrm{dm}^{-3}$ and $400 \mathrm{mg} \mathrm{dm}^{-3}$ phosphorus. The limestone doses were calculated by the base saturation method according to Raij (1981). The correctives used were calcium carbonate $\left(\mathrm{CaCO}_{3}\right)$ and magnesium carbonate $\left(\mathrm{MgCO}_{3}\right)$ in a ratio of 4:1, individually incorporated into the soil volume of each vessel containing $3.5 \mathrm{dm}^{3}$ of $\mathrm{dRL}$.
Monoammonium phosphate (MAP) was used as the phosphorus source, while the nitrogen was balanced with urea.

After applying the liming treatments, the soil was incubated with moisture corresponding to $60 \%$ of the total pore volume for a period of 20 days. The basic fertilization was carried out in all the experimental units with the following doses and sources: $0.5 \mathrm{mg}$ boron per $\mathrm{dm}^{3}$ of soil (boric acid ACS); $1.5 \mathrm{mg}$ copper per $\mathrm{dm}^{3}$ of soil (copper sulfate ACS); $3.0 \mathrm{mg}$ manganese per $\mathrm{dm}^{3}$ of soil (manganese sulfate ACS); $5.0 \mathrm{mg}$ zinc per $\mathrm{dm}^{3}$ of soil (zinc sulphate ACS); $0.1 \mathrm{mg}$ molybdenum per $\mathrm{dm}^{3}$ of soil (ammonium molybdate ACS), and $180 \mathrm{mg}$ potassium per $\mathrm{dm}^{3}$ of soil applied in three installments; the first one being 30 days after transplanting and the remainder every 20 days using potassium chloride as source (Carlos et al., 2014).

The seeds were obtained in the municipality of Felixlândia, Minas Gerais. They were benefited and then sown, and remained for eight months due to morphophysiological dormancy. They were removed from sowing and immersed in gibberellic acid solution $\left(\mathrm{GA}_{3}\right)$ at $500 \mathrm{ppm}$ for 24 hours at room temperature, then washed with distilled water and hypochlorite to disinfect the seeds and put in vermiculite until germination, according to the modified methodology of Silva et al. (2007) and Braga Filho (2014). Dormancy break occurred 30 days after with radicle protrusion, then pre-germinated seeds were transplanted to the pre-established treatments, maintaining irrigation to reach $60 \%$ of the field capacity.

The experiment lasted seven months with plant height, stem diameter and number of fully expanded leaves being evaluated. The seedlings were removed from the pots after the end of the nursery phase, washed in distilled water and separated into stem, leaves and roots. They were dried in a forced circulation air oven at $65^{\circ} \mathrm{C}$ until reaching constant weight. After drying, the material was weighed and shoot dry mass, root dry mass and total dry mass were obtained according to Hunt (1990). Additionally, the height/diameter, root/shoot ratio and Dickson quality index were calculated with the obtained variables (Dickson et al., 1960).

Table 1. Chemical and physical characterization of the soil in its natural condition.

\begin{tabular}{|c|c|c|c|c|c|c|c|c|c|c|}
\hline $\mathrm{Ca}$ & Mg & Al & $\mathbf{H}+\mathbf{A l}$ & SB & e & $\mathbf{E}$ & $\mathbf{P}$ & K & m & V \\
\hline \multicolumn{7}{|c|}{$\left(\mathrm{cmol}_{\mathrm{c}} \mathrm{dm}^{-3}\right)$} & \multicolumn{2}{|c|}{$\left(\mathbf{m g ~ d m}^{-3}\right)$} & \multicolumn{2}{|c|}{$\%$} \\
\hline 0.1 & 0.1 & 0.4 & 3.2 & 0.3 & 0.7 & 3.5 & 0.6 & 34 & 58 & 8.3 \\
\hline B & $\mathrm{Zn}$ & $\mathrm{Cu}$ & $\mathrm{Mn}$ & $\mathrm{Fe}$ & S & O.M. & $\mathrm{pH}$ & Sand & Clay & Silt \\
\hline \multicolumn{6}{|c|}{$\left(\mathrm{mg} \mathrm{dm} \mathrm{dm}^{-3}\right)$} & $\%$ & Water $(1: 2.5)$ & & $\%$ & \\
\hline 0.3 & 0.5 & 1.5 & 1.9 & 34.3 & 6 & 2.2 & 5.1 & 13 & 58 & 29 \\
\hline
\end{tabular}

Ca: calcium; Mg: magnesium; Al: aluminum; $\mathrm{H}+\mathrm{Al}$ : hydrogen plus aluminum; SB: sum of the bases; e: effective cation exchange capacity; E: cation exchange capacity at $\mathrm{pH}$ 7.0; P: phosphorus; K: potassium; m: aluminum saturation; V: base saturation; B: boron; $\mathrm{Zn}$ : zinc; Cu: copper; Mn: manganese; Fe: iron; S: sulfur; O.M.: organic material. 
In order to quantify the $\mathrm{Ca}, \mathrm{Mg}, \mathrm{P}, \mathrm{K}$ and $\mathrm{N}$ levels contained in the leaves, stems and roots of A. crassiflora seedlings, the dried vegetal material was ground in a Wiley mill, and $0.1 \mathrm{~g} \mathrm{~N}$ as well as $0.5 \mathrm{~g} \mathrm{Ca}, \mathrm{Mg}, \mathrm{P}$, and $\mathrm{K}$ were weighed and then calcined in flasks for extracting each macronutrient. $\mathrm{P}$ quantification occurred by spectrophotometer, whereas $\mathrm{Ca}$ and $\mathrm{Mg}$ were quantified via atomic absorption; $\mathrm{K}$ by flame emission photometer and $\mathrm{N}$ by means of nitrogen distiller and then determined by titration (Silva, 2009).

Data were submitted to the normality test, homogeneity of errors, and analysis of variance, and regression analysis was employed when the values were found to be significant up to $5 \%$ probability, using the Sisvar 5.3 statistical program (Ferreira, 2011).

\section{RESULTS}

There was no significant interaction between the elevation of base saturation and phosphorus doses for the characteristics evaluated in the A. crassiflora seedlings. However, the increase in the base saturation and phosphorus doses when analyzed separately promoted significant effects on the variables of height, stem diameter and number of leaves (Figure 1), total dry mass, shoot dry mass, root dry mass (Figure 2), and height/diameter ratio, root/shoot ratio and Dickson quality index (Figure 3).

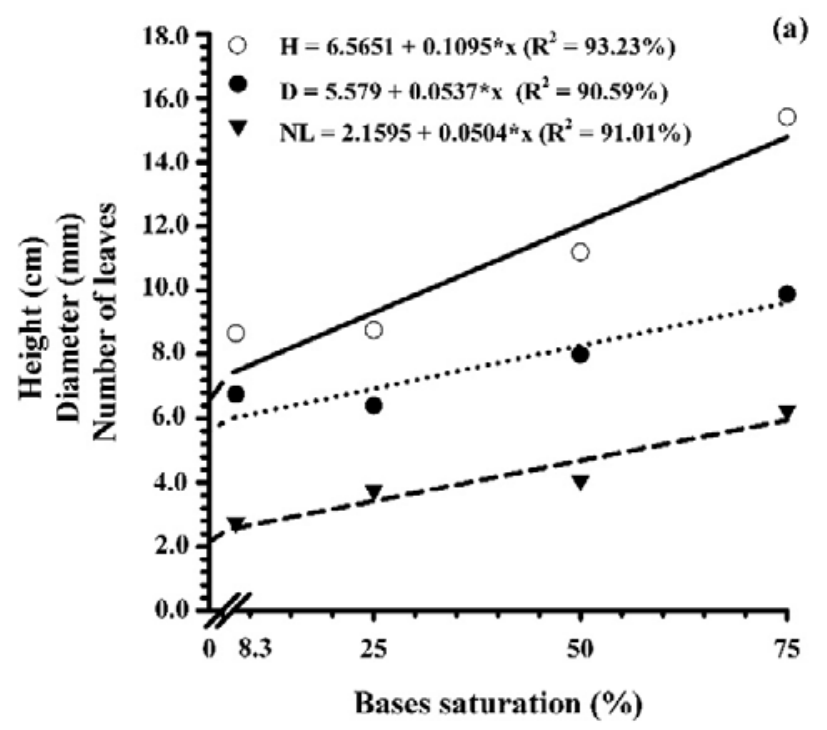

The increase in soil base saturation up to $75 \%$ promoted an increasing linear adjustment for the variables height, stem diameter and number of leaves presenting values estimated by the equations of $14.32 \mathrm{~cm}, 8.85 \mathrm{~mm}$ and 5.23 leaves, respectively (Figure 1a). Phosphorus doses also promoted an increasing linear effect, with $400 \mathrm{mg} \mathrm{dm}{ }^{3}$ being the dose that promoted the highest values in height, diameter and number of leaves, with values estimated by the equations of $14.78 \mathrm{~cm}, 9.61 \mathrm{~mm}$ and 5.94 leaves simultaneously (Figure 1b).

Considering the maximum mass accumulation point of shoot, root and total dry mass, they were obtained at the highest base saturation levels (75\%), with data being adjusted to the linear equation (Figure 2a). In relation to the phosphorus doses, there was also an increase in the seedling biomass accumulation, presenting increasing linear behavior, with the best response found at the highest dose of $400 \mathrm{mg} \mathrm{dm}^{-3}$ (Figure 2b).

Height/diameter ratio (H/D) and Dickson quality index (DQI) showed similar behavior in both plants submitted to the different liming levels and in the phosphorus doses, responding significantly to the treatment applications and presenting a linear behavior. Root/shoot (R/S) ratio showed quadratic behavior, but only for P doses (Figure 3).

The highest DQI and H/D ratio was obtained at the dose of $400 \mathrm{mg} \mathrm{dm}^{-3}$ phosphorus and $75 \%$ base saturation. On the other hand, as the saturation by base and phosphate fertilization increased, the R/S ratio decreased (Figure 3).

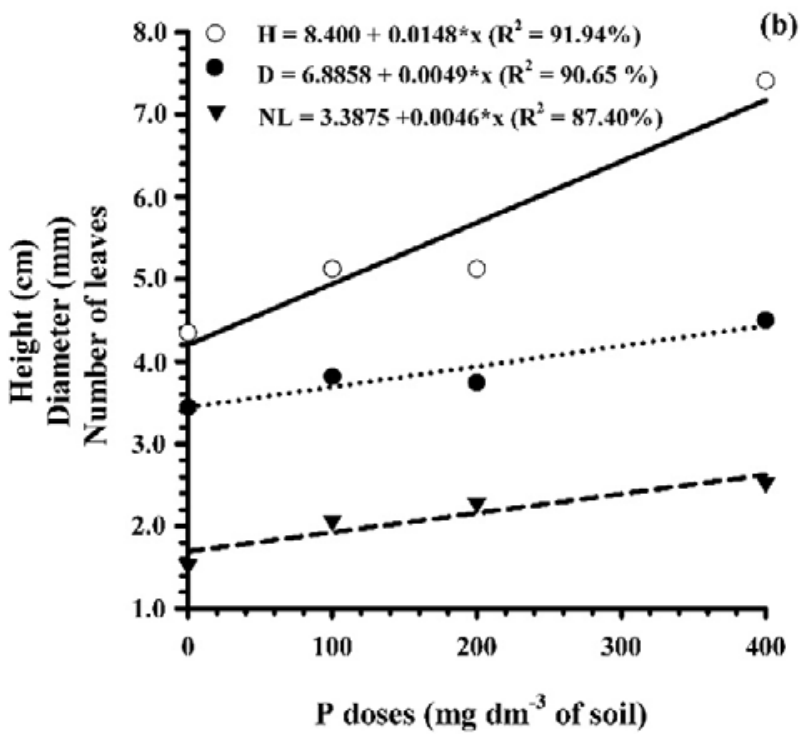

Figure 1. Plant height (H), stem diameter (D), number of leaves (NL) of A. crassiflora seedlings in response to base saturation (a) and phosphorus $(\mathrm{P})$ doses (b).

* Significant at $p \leq 0.05$. 

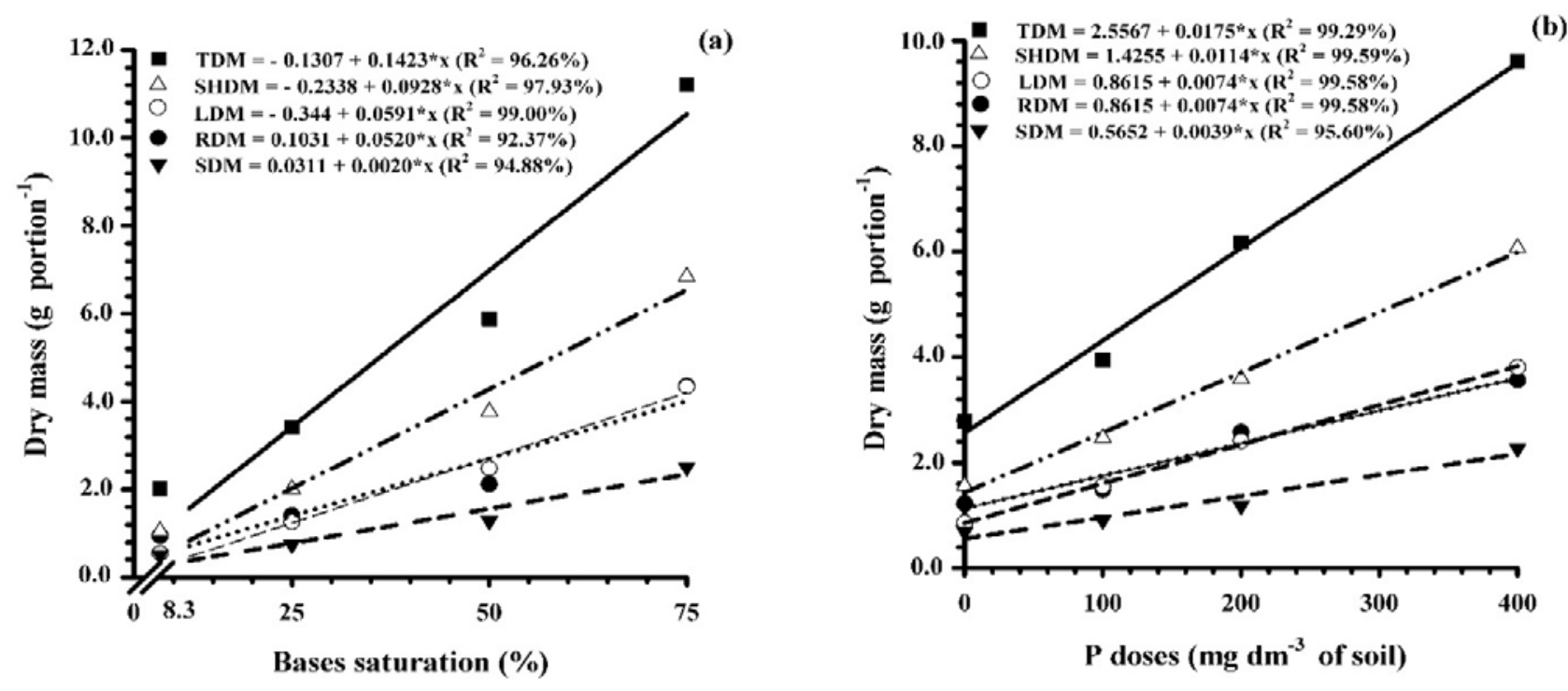

Figure 2. Total dry mass (TDM), shoot dry mass (SHDM), leaf dry mass (LDM), stem dry mass (SDM), and root dry mass (RDM) of A. crassiflora seedlings under different base saturation levels (a) and phosphorus (P) doses (b).

${ }^{*}$ Significant at $p \leq 0.05$.
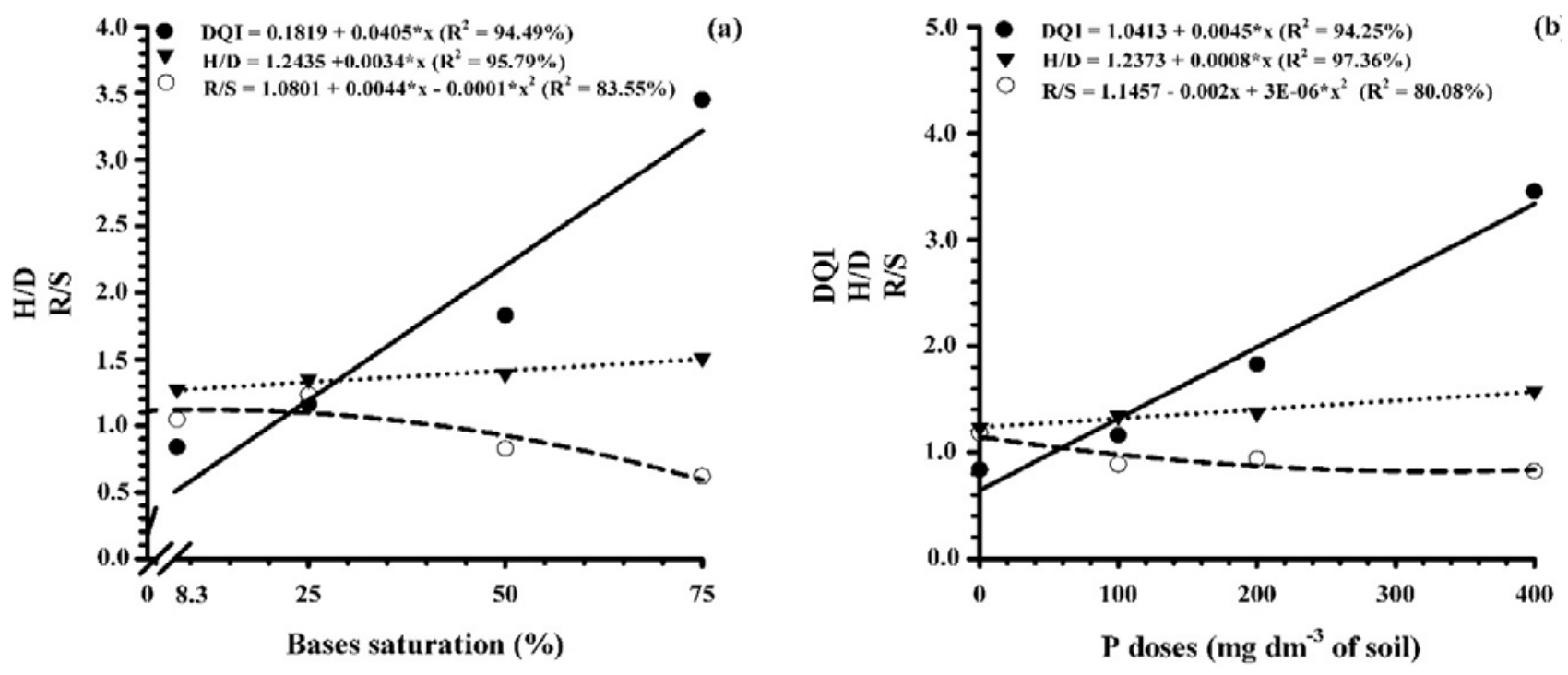

Figure 3. Dickson quality index (DQI), height/diameter ratio (H/D) and root/shoot ratio (R/S) from A. crassiflora seedlings under different base saturation levels (a) and phosphorus (P) doses (b).

* Significant at $p \leq 0.05$.

The increase in base saturation promoted a significant effect on the calcium content in the leaves, stem and root. The quadratic model fit the obtained data. It was verified that the maximum calcium content in the different parts of the plant (leaf, stem and root) was reached in $75 \%$ (Figure 4a). There was an increase in the calcium content in the roots and a decrease in the shoot with the increase in phosphorus levels in the soil (Figure 4b).
Phosphorus doses had a significant effect on magnesium content. The behavior that best fit was quadratic, except for the magnesium content in the stem. The root and stem were the organs that allocated the largest amount of magnesium with increased base saturation, presenting quadratic behavior. For the leaves, the highest magnesium content was obtained at the estimated dose of $29.83 \%$ (Figure 5). 

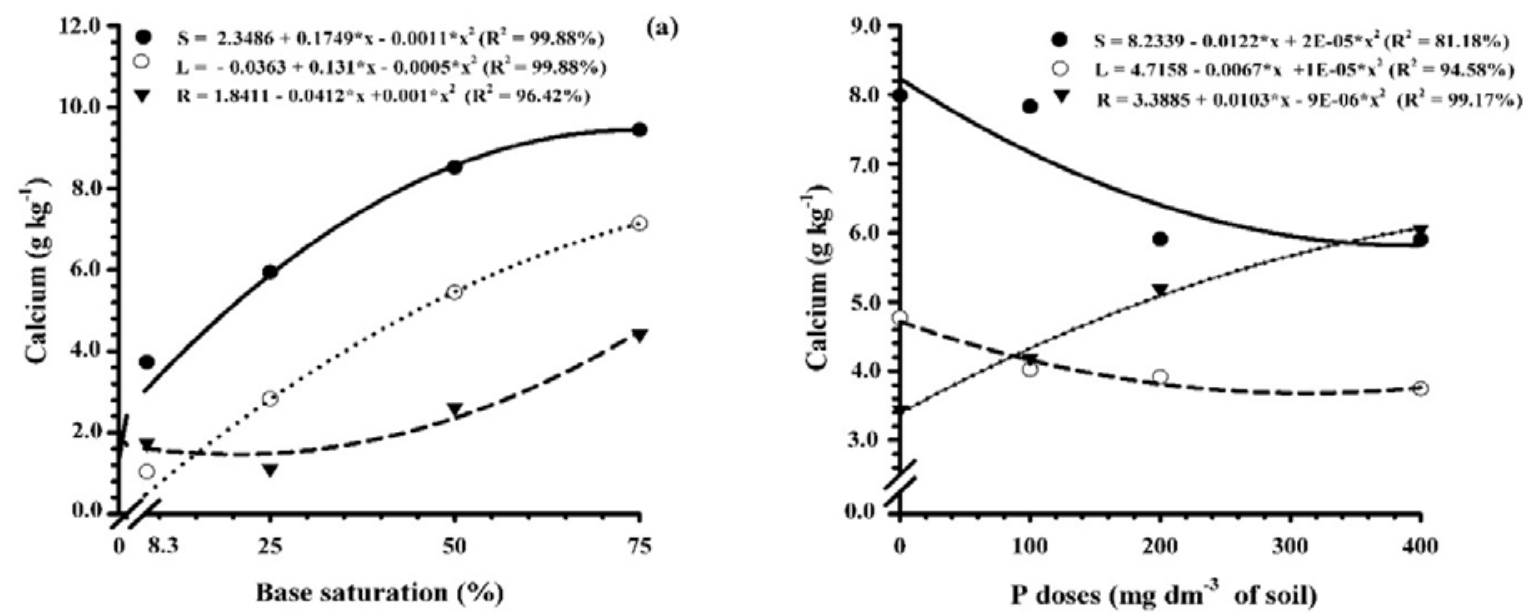

(a)

Figure 4. Calcium content in the leaves (L), stem (S) and root (R) of A. crassiflora seedlings in relation to base saturation levels (a) and phosphorus (P) doses (b).

* Significant at $p \leq 0.05$.
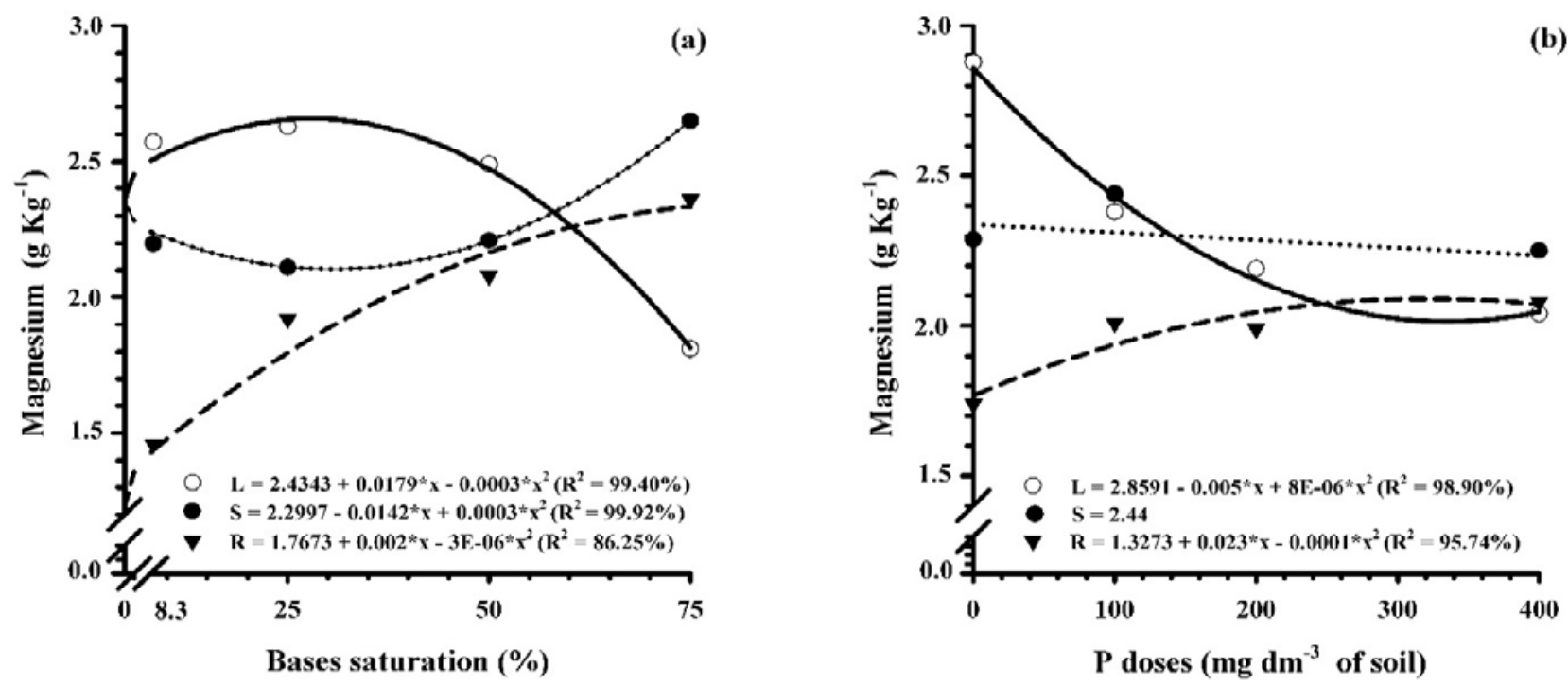

(b)

Figure 5. Magnesium content in the leaves (L), stem (S) and root (R) of A. crassiflora in relation to base saturation levels (a) and phosphorus (P) doses (b).

* Significant at $p \leq 0.05$

The highest phosphorus content in the leaves, stem and root of A. crassiflora seedlings was obtained at baseline saturation at $75 \%$ (Figure $6 \mathrm{a}$ ), although the data were adjusted to the quadratic model. However, phosphorus levels at different phosphorus doses (Figure 6b) showed that the highest root content was obtained by applying the highest dose $\left(400 \mathrm{mg} \mathrm{dm}^{-3}\right)$. Moreover, the shoot increased until the estimated dose of $283.33 \mathrm{mg} \mathrm{dm}^{-3}$ for the leaves and $270 \mathrm{mg} \mathrm{dm}^{-3}$ for the stem. From these doses there was a decrease in the contents with the increase in the phosphate fertilization. The quadratic model was the significant equation to represent the behavior.

For the nitrogen content, a significant effect was observed for the leaves, stem and root found at baseline saturation at $28.15 \%, 73.93 \%$ and $50 \%$ respectively, responding positively to the quadratic model (Figure 7a). For phosphate fertilization, a significant effect was also observed for the same variables, with the doses of $129 \mathrm{mg} \mathrm{dm}^{-3}$ leaf, $125 \mathrm{mg} \mathrm{dm}^{-3}$ stem and $100 \mathrm{mg} \mathrm{dm}^{-3}$ in the root, being adjusted to the quadratic model (Figure $7 \mathrm{~b}$ ). 

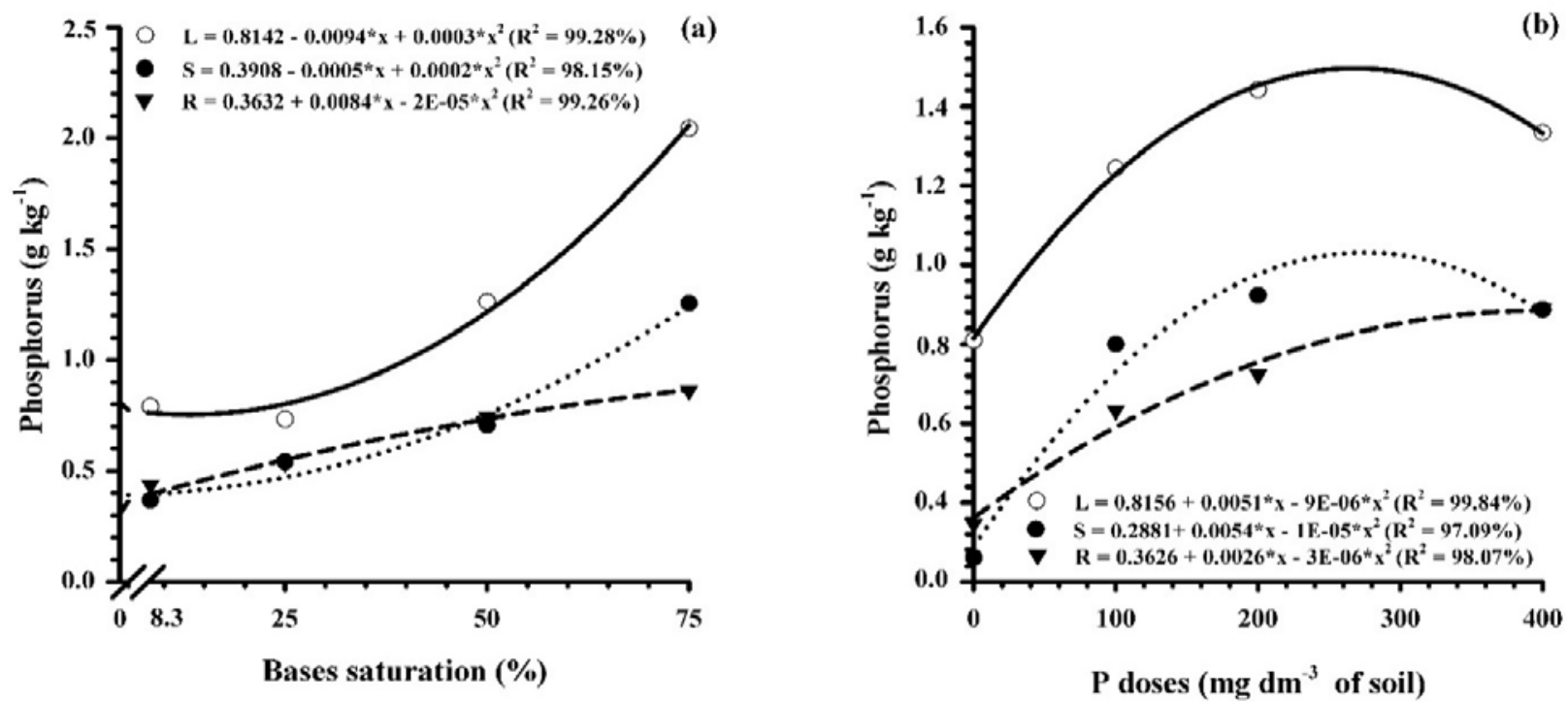

Figure 6. Phosphorus (P) content in leaves (L), stem (S) and root (R) of A. crassiflora seedlings in relation to base saturation levels (a) and $\mathrm{P}$ doses $(\mathrm{b})$.

* Significant at $p \leq 0.05$.
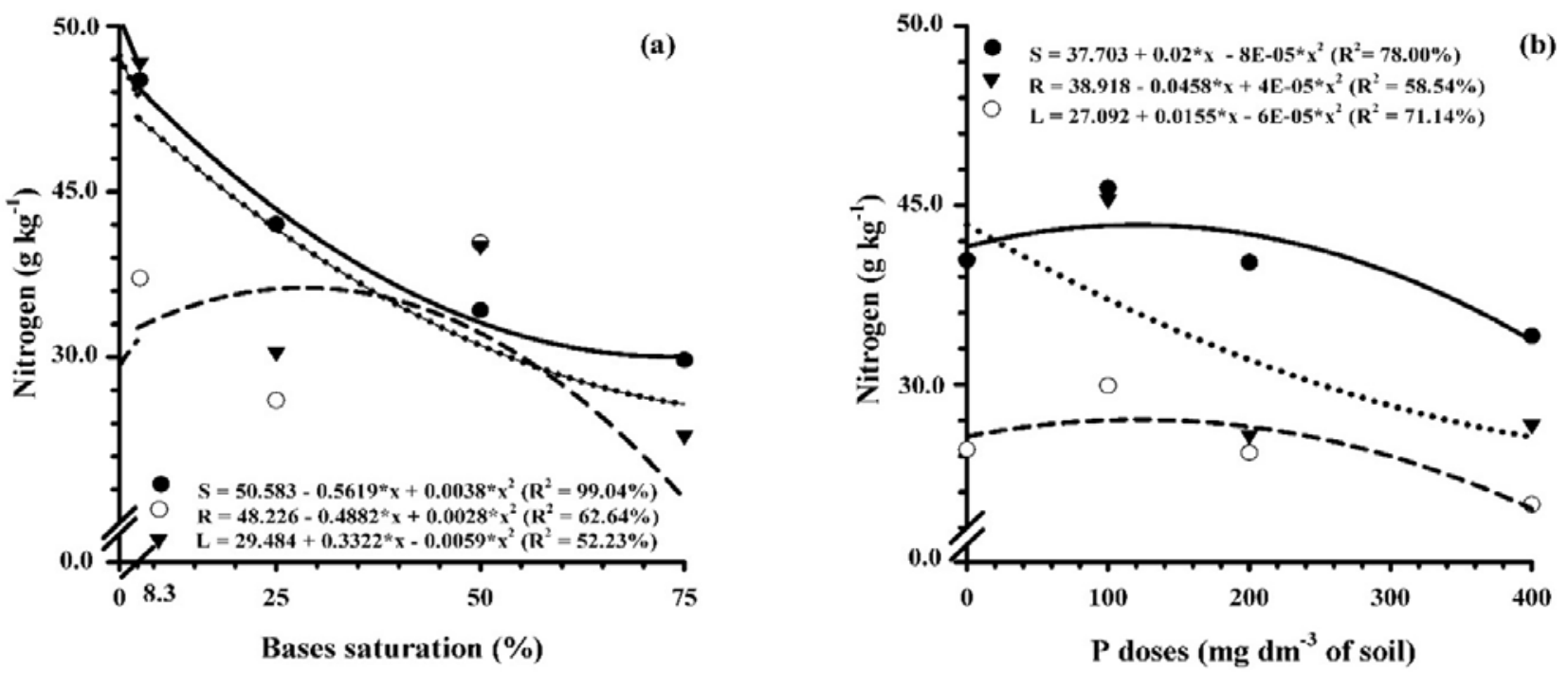

Figure 7. Nitrogen content in leaves (L), stem (S) and root (R) of A. crassiflora seedlings as a function of base saturation levels (a) and phosphorus $(\mathrm{P})$ doses $(\mathrm{b})$.

* Significant at $p \leq 0.05$.

The highest potassium content in leaves, stem and root were obtained at the levels estimated at 35.8\%, 21.2\% and $59.22 \%$, respectively, while the best fit equation was the quadratic model (Figure 8a). The phosphorus doses that promoted the highest potassium content were $240 \mathrm{mg} \mathrm{dm}^{-3}$ and $265 \mathrm{mg} \mathrm{dm}^{-3}$ in leaves and stem, respectively. A significant effect was observed for the quadratic model. The potassium content in the root was influenced by the $400 \mathrm{mg} \mathrm{dm}^{-3}$ dose of phosphorus in an increasing linear fashion (Figure 8b). 

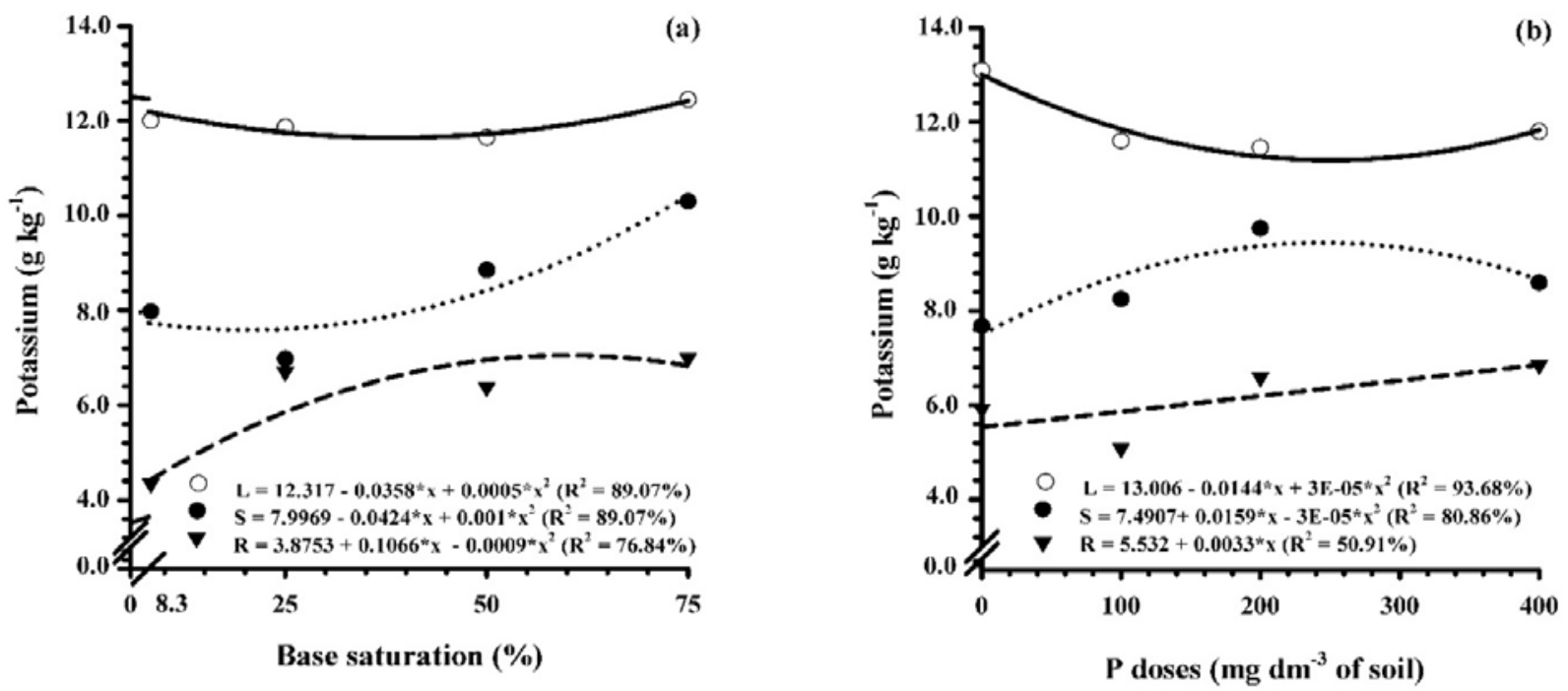

Figure 8. Potassium content in leaves (L), stem (S) and root (R) of A. crassiflora seedlings as a function of base saturation levels (a) and phosphorus (P) doses (b).

* Significant at $p \leq 0.05$.

\section{DISCUSSION}

Positive results have been recorded when it comes to phosphate fertilization. This fertilization was favorable to the growth of several forest and native species of the Cerrado, such as macaúba (Acrocomia aculeata (Jacq.) Lodd. ex Mart.) (Pimentel et al., 2016), barbatimão (Stryphnodendron adstringens (Mart.) Coville.) (Carnevali et al., 2016), jatobádo-cerrado (Hymenaea stigonocarpa Mart. ex Hayne) (Alves et al., 2015), pear tree (Pyrus communis L.) (Brunetto et al., 2015), kingwood (Astronium fraxinifolium Schott), black wattle (Acacia mangium Willd.) (Valadares et al., 2015), Bahia rosewood (Dalbergia nigra (Vell.) Allemão ex Benth) (Carlos et al., 2015) and eucalyptus (Eucalyptus grandis) (Tng et al., 2014).

These results are found due to the benefits that phosphate fertilization promotes in plants, as verified in this study. Plants that are well nourished in terms of phosphorus are able to potentiate vital processes such as photosynthesis, thereby fixing and incorporating higher $\mathrm{CO}_{2}$ concentrations in organic matter (Shabnam \& Iqbal, 2016), through the transfer of energy (ATP, NADPH, ADP and NADP) of phospholipids, phosphoproteins and nucleic acids (Taiz \& Zeiger, 2017), thus promoting biomass gain seen in the growth itself by increasing the size and volume of the A. crassiflora seedlings, constituting an important indicator of the morphological behavior of a plant development. The same would not be possible with only a simple record of the nutritional content of the seedlings (Pedó et al., 2014).

The increase in base saturation levels positively influenced the growth of A. crassiflora seedlings. This effect was not only observed in this study, but in several others involving several species such as Pinus taeda L. (Batista et al., 2015), Toona ciliata M. Roem var. australis (Braga et al., 2015), Fagus sylvatica L. (Forey et al., 2015), Juglans regia L., Robinia pseudoacacia L. and Eucalyptus sp. (Chatzistathis et al., 2015). However, this does not apply to all species, as there are those that respond in the opposite way to the one found in this study, and there are those that do not even respond to the effect of liming; among these species are Astronium fraxinifolium Schott, Guazuma ulmifolia Lam., Anadenanthera macrocarpa (Benth.) Brenan and Inga edulis Mart. (Silva et al., 2011). This is related to the fact that some species evolutionarily develop tolerance mechanisms to aluminum toxicity with the capacity to adapt to acidic soils, and therefore do not respond to limestone application, being that the calcium and magnesium contents contained in the soil in natural conditions are sufficient to meet the requirements of these species during its initial phase (Santin et al., 2013).

The increase in the base saturation levels in an isolated way promoted an increase in the $\mathrm{P}, \mathrm{Ca}, \mathrm{Mg}, \mathrm{N}$ and $\mathrm{K}$ levels in the A. crassiflora seedlings, considering the optimal absorption range for each nutrient. These results indicate greater absorption of these nutrients to invest in the seedlings' 
growth and development. This is because all of these nutrients have different functions in plants, and they are considered essential chemical elements to which plants respond positively due to their concentration and quantity accumulated in plant tissues, while their absence prevents plants from completing their life cycle (Arnon \& Stout, 1939).

Due to its low mobility in the plant, calcium acts on cell signaling regulating changes in cytoplasmic concentration, associated with the regulation of stomatal control (Peuke, 2016). When the calcium demand is reached, homeostatic balance is also reached. If this equilibrium is disturbed, it can cause a series of unfavorable physiological conditions due to diffusive limitations or biochemical alterations (Atkinson, 2014) and compromise the growth and development of seedlings. Particularly, it favors water absorption/retention and allows the exploitation of larger soil volume (Violante \& Caporale, 2015). Thus, calcium deficiency in the soil can inhibit and hinder the absorption of several nutrients, as well as influence the growth of forest and tree species (Freitas et al., 2017).

According to the results obtained in this study, it was verified that $A$. crassiflora is demanding in phosphorus. This is because phosphorus deficiency can adversely affect the relative growth of plants, impairing the seedling quality. In addition, the absence of this nutrient reduces shoot growth, increasing the efficiency of the root system able to modulate the acquisition of nutrients through alterations in its architecture, enabling the plant to extract enough phosphorus to meet its demands (Deng et al., 2015; Vadez, 2014).

The decrease in the N, P and Mg contents in the seedlings is due to the dilution effect of these nutrients in the plant due to the growth of the A. crassiflora seedlings. Both the increase in the base saturation and the phosphorus doses resulted in increased productivity, and this affects the absorption and translocation of these ions to the shoot, resulting in a plant with a lower content (Studer et al., 2017).

The elevation in base saturation increased the calcium concentration observed during the growth and development of A. crassiflora seedlings. This was already predicted for $\mathrm{Ca}$ which is regarded as a low mobility plant nutrient (Peuke, 2016). In addition to this dilution effect, there was also a competition effect between $\mathrm{Ca}, \mathrm{K}$ and $\mathrm{Mg}$ ions in the exchange sites. This result can be attributed to the increase in $\mathrm{Ca}$ and $\mathrm{K}$ concentrations in the tissues, reducing the $\mathrm{Mg}$ content in A. crassiflora plants, since $\mathrm{Ca}$ and $\mathrm{Mg}$ have an antagonistic effect, with an excess in one impairing the absorption of the other (Waraich et al., 2011). Phosphorus doses affected the magnesium content because the A. crassiflora seedlings allocated more $\mathrm{Mg}$ in the leaves in relation to the root and the stem.
In general, the content and accumulation of nutrients can be considered good development predictors of the morphophysiological strategies of plants, as in the case of A. crassiflora, indicating the ability of this species to attenuate its morphological responses in acquiring nutrients in response to mineral fertilization. This occurs due to the phosphorus supply and the base saturation levels at the beginning of the vegetative cycle, influencing the demand of photoassimilates that are destined to form several organs and tissues (Crusciol et al., 2016).

\section{CONCLUSIONS}

Phosphate fertilization and the increase in base saturation promoted satisfactory growth and development of $A$. crassiflora seedlings, so that the best results were found at the highest levels tested for both phosphorus $\left(400 \mathrm{mg} \mathrm{dm}^{-3}\right)$ and liming (75\%).

\section{ACKNOWLEDGEMENTS}

The authors thank the Coordenação de Aperfeiçoamento de Pessoal de Nível Superior (Capes) for the scholarship, and the Instituto Federal de Educação, Ciência e Tecnologia Goiano (IF Goiano) Rio Verde campus - for the financial support.

\section{CORRESPONDENCE TO}

\section{Leandro Carlos}

Instituto Federal de Educação, Ciência e Tecnologia Goiano (IFG), Rod. Sul Goiana, km 1, Zona Rural, CEP 75901-970, Rio Verde, GO, Brasil

e-mail: leandro.carlos@ifgoiano.edu.br

\section{SUBMISSION STATUS}

Received: 25 June 2018

Accepted: 13 Sept. 2018

Associate editor: Eduardo Vinicius da Silva

(D) 0000-0002-1115-0624

\section{REFERENCES}

Alves JDN, Souza FCA, Oliveira ML, Oliveira MCMA, Okumura RS. Fontes de fósforo no crescimento inicial de mudas de jatobádo-cerrado (Hymenaea stigonocarpa Mart.). Nucleus 2015; 12(2): 299-307. 10.3738/1982.2278.1460

Arnon DI, Stout PR. The essentiality of certain elements in minute quantity for plants with special reference to copper. Plant Physiology 1939; 14(1): 371-375. 10.1104/pp.14.2.371

Atkinson CJ. Is xylem sap calcium responsible for reducing stomatal conductance after soil liming? Plant and Soil 2014; 382(1-2): 349-356. 10.1007/s11104-014-2180-z 
Batista AH, Motta ACV, Reissmann CB, Schneider T, Martins IL, Hashimoto M. Liming and fertilisation in Pinus taeda plantations with severe nutrient deficiency in savanna soils. Acta Scientiarum Agronomy 2015; 37(1): 117-125. 10.4025/actasciagron.v37i1.18061

Bailão EFLC, Devilla IA, Conceição EC, Borges LL. Bioactive compounds found in Brazilian Cerrado fruits. International Journal of Molecular Sciences 2015; 16(10): 23760-23783. 10.3390/ ijms 161023760

Botrel DA, Rodrigues ICB, Souza HJB, Fernandes RVB. Application of inulin in thin-layer drying process of araticum (Annona crassiflora) pulp. LWT - Food Science and Technology 2016; 69: 32-39. 10.1016/j. lwt.2016.01.018

Braga MM, Furtini Neto AE, Oliveira AH. Influência da saturação por bases na qualidade e crescimento de mudas de cedro-australiano (Toona ciliata M. Roem var. australis). Ciência Florestal 2015; 25(1): 49-58. 10.1590/1980-509820152505049

Braga Filho JR, Naves RV, Chaves LJ, Souza ERB, Mazon LT, Silva LB. Germinação de sementes e emergência de plântulas de araticum oriundos do cerrado de goiás. Bioscience Journal 2014; 30(1): 74-81.

Brunetto G, Nava G, Ambrosini VG, Comin JJ, Kaminski J. The pear tree response to phosphorus and potassium fertilization. Revista Brasileira Fruticultura 2015; 37(2): 507-516. 10.1590/0100-2945-027/14

Carnevali NHS, Marchetti ME, Vieira MC, Carnevali TO, Ramos DD. Eficiência nutricional de mudas de Stryphnodendron polyphyllum em função de nitrogênio e fósforo. Ciência Florestal 2016; 26(2): 449-461. 10.5902/1980509822746

Carlos L, Venturin N, Farias ES, Venturin RP, Macedo RLG. Growth and mineral nutrition in seedlings of Jacarandá-da-Bahia subjected to nutrient deprivation. Floresta 2015; 45(1): 107-116. 10.5380/ rf.v45i1.34312

Carlos L, Venturin N, Macedo RLG, Venturin RP, Soares AAV, Toledo FHSF. Growth and mineral nutrition in Annona crassiflora Mart. seedlings subjected to nutrient deprivation. Australian Journal of Basic and Applied Sciences 2014; 8(13): 379-384.

Chatzistathis T, Alifragis D, Papaioannou A. The influence of liming on soil chemical properties and on the alleviation of manganese and copper toxicity in Juglans regia, Robinia pseudoacacia, Eucalyptus sp. and Populus sp. plantations. Journal of Environmental Management 2015; 150: 149-156. 10.1016/j.jenvman.2014.11.020

Crusciol CAC, Fernandes AM, Carmeis Filho ACA, Alvarez RCF. Macronutrient uptake and removal by upland rice cultivars with different plant architecture. Revista Brasileira de Ciência do Solo 2016; 40(1): e0150115. 10.1590/18069657rbcs20150115

Deng Q, Hui D, Luo Y, Elser J, Wang YP, Loladze I, Zhang Q, Dennis S. Down-regulation of tissue N:P ratios in terrestrial plants by elevated $\mathrm{CO}_{2}$. Ecology 2015; 96(12): 3354-3362. 10.1890/15-0217.1

Dickson A, Leaf AL, Hosner JF. Quality appraisal of white spruce and white pine seedling stock in nurseries. The Forest Chronicle 1960; 36(1): 10-13. 10.5558/tfc36010-1

Empresa Brasileira de Pesquisa Agropecuária - Embrapa. Sistema brasileiro de classificação de solos. 3rd ed. Brasília: Embrapa; 2013.

Ferreira DF. Sisvar: a computer statistical analysis system. Ciência e Agrotecnologia 2011; 35(6): 1039-1042. 10.1590/S141370542011000600001

Ferreira RB, Oliveira Júnior JP, Naves RV, Salgado AL. Desenvolvimento de mudas de Annona crassiflora Mart. (Araticum) em substratos com cinza de bagaço de cana. Pesquisa Agropecuária Tropical 2009; 39(1): 18-24.
Forey E, Trap J, Aubert M. Liming impacts Fagus sylvatica leaf traits and litter decomposition 25 years after amendment. Forest Ecology and Management 2015; 353: 67-76. 10.1016/j.foreco.2015.03.050

Freitas ECS, Paiva HN, Leite HG, Oliveira Neto SN. Crescimento e qualidade de mudas de Cassia grandis Linnaeus f. em resposta à adubação fosfatada e calagem. Ciência Florestal 2017; 27(2): 509-519. $10.5902 / 1980509827732$

Freitas RMO, Nogueira NW, Pinto JRS, Tosta MS, Dombroski JLD. Fertilizante fosfatado no desenvolvimento inicial de mudas de pinheira. Bioscience Journal 2013; 29(2): 319-327.

Hunt R. Basic growth analysis: plant growth analysis for beginners. London: Unwim Hyman; 1990.

Li J, Guo Q, Zhang J, Korpelainen H, Li C. Effects of nitrogen and phosphorus supply on growth and physiological traits of two Larix species. Environmental and Experimental Botany 2016; 103: 206-215. 10.1016/j.envexpbot.2016.06.006

Pedó T, Aumonde TZ, Martinazzo EG, Villela FA, Lopes NF, Mauch CR. Análise de crescimento de plantas de rabanete submetidas a doses de adubação nitrogenada. Bioscience Journal 2014; 30(1): 1-7.

Peuke AD. ABA flow modelling in Ricinus communis exposed to salt stress and variable nutrition. Journal of Experimental Botany 2016; 67(18): 5301-5311. 10.1093/jxb/erw291

Pimentel LD, Bruckner CH, Manfio CE, Motoike SY, Martinez HEP. Substrate, lime, phosphorus and topdress fertilization in macaw palm seedling production. Árvore 2016; 40(2): 235-244. 10.1590/0100-67622016000200006

Raij BV. Avaliação da fertilidade do solo. Piracicaba: Instituto da Potassa e Fosfato, 1981.

Rozane DE, Natale W. Calagem, adubação e nutrição mineral de anonáceas. Revista Brasileira de Fruticultura 2014; 36(spe1): 166175. 10.1590/S0100-29452014000500020

Santin D, Benedetti EL, Kaseker JF, Bastos MC, Reissmann CB, Wendling I, Barros NF. Nutrição e crescimento da ervamate submetida à calagem. Ciência Florestal 2013; 23(1): 55-66. $10.5902 / 198050988439$

Shabnam R, Iqbal MT. Understanding phosphorus dynamics on wheat plant under split-root system in alkaline soil. Brazilian Journal of Science and Techology 2016; 3(19): 1-16. 10.1186/s40552-016-0031-6

Silva AH, Pereira JS, Rodrigues SC. Desenvolvimento inicial de espécies exóticas e nativas e necessidade de calagem em área degradada do Cerrado no triângulo mineiro (Minas Gerais, Brasil). Agronomía Colombiana 2011; 29(2): 287-292.

Silva EAA, Melo DLB, Davide AC, Bode N, Abreu GB, Faria JMR, Hilhorst HW. Germination ecophysiology of Annona crassiflora seeds. Annals of Botany 2007; 99(5): 823-830. 10.1093/aob/mcm016

Silva FC, editor. Manual de análises químicas de solos, plantas e fertilizantes. 2nd ed. Brasília: Embrapa; 2009.

Souza FF, Braga RM, Venturin N, Macedo RLG, Carlos L, Venturin RP. Exigências nutricionais de mudas de Dipteryx alata sob limitação nutricional. Ciência Florestal 2018; 28(1): 102-114. $10.5902 / 1980509831586$

Studer C, Hu Y, Schmidhalter U. Interactive effects of N, P and K nutrition and drought stress on the development of maize seedlings. Agriculture 2017; 7(11): 90. 10.3390/agriculture7110090

Tng DYP, Janos DP, Jordan GJ, Weber E, Bowman DMJS. Phosphorus limits Eucalyptus grandis seedling growth in an unburnt rain forest soil. Frontiers in Plant Science 2014; 5: 527. $10.3389 /$ fpls.2014.00527 
Taiz L, Zeiger E. Fisiologia vegetal. 6th ed. Porto Alegre: Artmed, 2017.

Vadez V. Root hydraulics: the forgotten side of roots in drought adaptation. Field Crops Research 2014; 165: 15-24. 10.1016/j. fcr.2014.03.017

Valadares SV, Silva LF, Valadares RV, Fernandes LA, Neves JCL, Sampaio RA. Plasticidade fenotípica e frações fosfatadas em espécies florestais como resposta à aplicação de fósforo. Árvore 2015; 39(2): 225-232. 10.1590/0100-67622015000200002

Violante A, Caporale AG. Biogeochemical processes at soilroot interface. Journal of Soil Science and Plant Nutrition 2015; 15(2): 422-448. 10.4067/S0718-95162015005000038

Waraich EA, Ahmad R, Ashraf MY. Role of mineral nutrition in alleviation of drought stress in plants. Australian Journal of Crop Science 2011; 5(6): 764-777. 